\title{
COUPLING CLIMATE CONDITIONS, SEDIMENT SOURCES AND SEDIMENT TRANSPORT IN
}

\section{AN ALPINE BASIN}

\section{ABSTRACT}

In a fluvial system, mountain basins control sediment export to the lowland rivers. Hence, analysis of erosion processes and sediment delivery patterns in mountain basins is a key factor for many applications such as land-use management, hazard assessment, and infrastructure design. Several studies have investigated the alterations triggered by recent climatic change on the hydrological regime, whilst only a few works have explored the consequences on fluvial sediment dynamics. Here we combined and analyzed the quasi-unique dataset of climatic conditions, landform response, and sediment export produced, since 1986 in the Rio Cordon basin $\left(5 \mathrm{~km}^{2}\right.$, Eastern Italian Alps) to examine the sediment delivery processes occurring in the last three decades. The temperature, precipitation, and fluvial sediment fluxes in the basin were analyzed using continuous measurement executed by a permanent monitoring station, while the evolution of sediment source areas was investigated using three sediment source inventories. The results showed that during the period 1986-1993 the sediment fluxes $\left(339 \mathrm{Mg} \mathrm{yr}^{-1}\right)$ reflected the stable trend of the climatic conditions. The period between the first and second source inventory (i.e. 1994-2006) was characterized by climatic fluctuations and by the occurrence of high magnitude floods. Nevertheless, a limited increase in the extent of sediment source areas was detected, suggesting that the increased sediment export ( $\left.759 \mathrm{Mg} \mathrm{yr}^{-1}\right)$ was mainly driven by in-channel sediment supply. Notwithstanding the marked climate warming and the increased precipitation, a weak source area evolution and a reduction in sediment export $\left(237 \mathrm{Mg} \mathrm{yr}^{-1}\right)$ were observed 
during the period 2007-2015. In particular, the higher rainfall did not result in an intensification of flood

31 32

33

34

35

events, stressing the absence of hillslope-channel connectivity.

Key-words: Alpine basin; climate change; sediment sources evolution; source area; sediment connectivity; sediment transport.

\section{INTRODUCTION}

The land degradation acting in high mountain basins can lead to significant alterations to the local fluvial system, influencing channel morphology, sediment dynamics, natural hazards, and biodiversity; changes that can be rapidly transmitted downstream (Keesstra et al., 2005; Liebault et al., 2005, Comiti et al., 2011; Moretto et al., 2014; Picco et al., 2016; Tarolli \& Sofia, 2016). Erosion processes in mountain basins are influenced by several factors such as climate, topography, lithology and paraglacial adjustments (Montgomery \& Buffington, 1997; Jones, 2000; Le Pera \& Sorriso-Valvo, 2000; Carrivick \& Chase, 2011; Fischer et al., 2014). The key role played by climatic conditions was particularly evident in recent decades due to climate change (Bennett et al., 2013). Climate change may strongly affect not only water discharge (Menzel \& Burger, 2003), riverine habitat and water quality (Ashmore \& Church, 2001), but also soil erosion and subsequent sediment fluxes along different channel networks (Michael et al., 2005; Syvitski et al., 2005). For instance, Zhu et al. (2008)-reported changes in sediment fluxes in the Longchuanjiang catchment (China) after changes in temperature and rainfall. Moreover, increasing attention has been devoted to the direct relationship between changing climate and rising flood risk (Milly et al., 2002; Hirabayashi et al., 2013). In alpine basins sediment production and export seem to be affected by recent climatic variations. These effects could be particularly marked since, during the last century, the alpine range experienced a temperature increase $\left(\sim 2^{\circ} \mathrm{C}\right)$ higher than central Europe (Hinderer et al., 2013). Climate variability, especially in terms of temperature and precipitation, can lead to temporal trends in the hydrological regime and sediment dynamics, with significant implications for channel morphology and landform dynamics (Morche et al., 2012; Geilhausen et al., 2013; Baewert \& Morche, 2014; Micheletti \& Lane, 2016). Rainfall and temperature regimes cause erosion and weathering in the basin, controlling sediment production (Buendia et al., 2016). In conjunction with soil infiltration capacity (Harden \& Scruggs, 2003), temperature variations control the erosion and dispersion of sediments from potential sources, especially by periodical 
freeze-thaw processes (López-Tarazón et al.; 2012). Sass \& Oberlechner (2012), analyzing the Austrian

60

61 rockfall inventory (252 events over the last century), observed higher rockfall activity during colder years. The author attributed this tendency to bedrock contraction and cleft propagation occurring with low temperatures. In glaciated basins, climate warming may lead increased water yield (Micheletti \& Lane, 2016), as well as increased sediment export by inducing permafrost degradation (Bennett et al., 2013) or by favoring the development of an enhanced sediment connectivity, as observed in the Haut Glacier d'Arolla (Swiss Alps) by Lane et al. (2017). On the other hand, precipitation patterns act both on sediment erosion along the hillslope (Rossi et al., 2010) and on the runoff regime (Bocchiola, 2014). Several studies have explored the effects of recent climatic shifts on the hydrological regime (Geilhausen et al., 2013; Bennett et al., 2014), whilst the impacts on fluvial sediment dynamics have been poorly investigated due to a limited number of long-lasting monitoring programs (Lane et al., 2017). Very few mountain basins are instrumented to investigate contemporary climate and hydrological trends, along with changes in sediment source areas and sediment fluxes, and thus, few quantitative long-term datasets ( $>10 \mathrm{yr})$ are available. Studies which do capture these datasets were mainly conducted in glaciated or formerly glaciated basins, rarely focusing on non-glacial catchments. Analyzing two small and partially glaciated mountain catchments located in the Canton of Valais (Swiss Alps), Micheletti \& Lane (2016) observed that climate variations occurring in the last three decades led to an increase in water yield and sediment transport capacity, but this trend was not accompanied by an increase in sediment export due to low hillslope-channel connectivity. Nonlinear behavior between rainfall, discharge, and sediment export was observed by Lana-Renault et al. (2007) in a small unglaciated Pyrenees basin, highlighting the complexity of sediment dynamics in the catchment. The authors observed that rainfall is not the most significant controlling factor of sediment yield, stressing the importance of the continuity of cascading sediment flux, and thus, of sediment connectivity (e.g., Cavalli et al., 2013; Heckmann \& Schwanghart, 2013). This evidence seems to suggest that in dynamic systems such as mountain catchments climatic conditions permit only partial description of sediment export. By producing change in sediment storage landforms, erosion processes can lead to the creation of sediment sources, that in the mountain basins can vary from large debris flow-channels and -deposits to shallow landslides (Lenzi et al., 2003; Messenzehl et al. 2014; Cavalli et al., 2017). Thus, by acting on the source areas, sediment erosion strongly controls fluvial sediment transport, which is essentially related to hydrological and sediment supply 
87

88

89

90

91

92

93

94

95

96

97

98

100

101

102

103

104

105

106

107

108

109

110

111

\section{MATERIAL AND METHODS}

\section{Study area}

conditions (Mao et al., 2009; Recking, 2012). In particular, the source areas control the amount of material delivered to the channel network, also defining in-channel features and influencing sediment mobility conditions (Yu et al., 2009, Piton \& Recking, in press). This is particularly evident in small mountain basins, where the type and extent of sediment sources may strongly influence the nature, magnitude, and efficiency of fluvial transport processes (Schuerch et al., 2009; Rainato et al., 2017). The material supplied by the slopes may reach the channel network or not, depending on couplingldecoupling relationships between sediment sources and the channel network. In light of this, the sediment yield exhibited by the mountain basins, further to the climatic and hydrological conditions, is strongly controlled by the connectivity between source areas and the channel network (Bracken et al., 2015; Dell'Agnese et al., 2015). The presence/absence of hillslope-channel network coupling, and its degree, can influence the temporal response of the catchment to sediment supply variation. Indeed, a lagged response of basins, despite increased hillslope erosion, can be due to the absence of sediment connectivity between the slopes and drainage network (Bennett et al., 2013; Messenzehl et al., 2014). In this respect, small mountain basins offer a great opportunity to assess the sediment cascade continuity, since here hillslope-channel network coupling is characterized by rapid connectivity, both temporally and spatially (Sanjuán et al., 2016).

This work aims to investigate the climate trends, evolution of sediment source areas, and fluvial sediment fluxes in an alpine basin over the last three decades. The quasi-unique monitoring program maintained in the Rio Cordon basin since 1986 allows us to: i) analyze the shifts in temperature and precipitation regimes, and ii) evaluate the response of sediment source areas; specifically, in terms of source evolution. After defining the sediment connectivity acting in the catchment, changes observed in the climate trends and source areas were compared to the sediment fluxes independently recorded at the outlet of the basin. Hence, the quasiunique dataset provided by the Rio Cordon monitoring program was used to shed further light on the central, but only rarely analyzed, cause-effect coupling between climate forcing and sediment delivery patterns, providing insights to be compared with other monitored catchments. 
114 Rio Cordon is a mountain basin located in the eastern Italian Alps (Dolomites). The catchment (Figure 1)

115 covers an area of $5 \mathrm{~km}^{2}$ and the elevation ranges from 1,763 to 2,763 m.a.s.l.. While the average slope is $27^{\circ}$, 116 this is locally exceeded along the subvertical cliffs located in the upper part of the basin, where slopes higher than $45^{\circ}$ were detected (Trevisani et al., 2010). The basin is part of the Southern Calcareous Alps with

118 prevalent dolomite and volcanic conglomerates (Wengen group) in the upper part, whereas sandstones and 119 calcareous-marly rocks (Buchenstein group) characterize the lower part. Additionally, a wide presence of 120 quaternary deposits (i.e. moraines, scree, and landslide accumulations) can be observed throughout the study 121 area (Cavalli et al., 2016). In the basin three main soil-types are noticeable: brown earth-soil is widely spread, while the skeleton- and organic-soils are mainly present on the partially vegetated steep slopes and in the lower vegetated areas, respectively (Lenzi et al., 2004).

\section{\#\#\#\#\#\# Figure 1 \#\#\#\#\#\#}

In terms of climate, the Rio Cordon basin is characterized by alpine climatic conditions with an average annual precipitation of $1,150 \mathrm{~mm}$. Between November and April, the precipitation occurs mainly as snowfall, while during the rest of the year rainfall prevails. Consequently, the runoff exhibits a typical nivopluvial regime with snowmelt during the May-June period and periodical floods in summer and autumn due to rainstorm and persistent rainfall, respectively.

In relation to the sediment cascade, the basin exhibits a wide presence of sediment sources, which consist mainly of debris flow-channels and -deposits, landslides, and talus slopes. Overall, these areas cover roughly $13 \%$ of the basin (Ferrato et al., 2017). Due to the presence of a low-gradient belt located at approximately 2,200 m.a.s.l., the upstream sources provide a minor contribution to the sediment export (Dalla Fontana \& Marchi, 2003). Currently, the basin appears to be characterized by a low-moderate sediment supply condition (Rainato et al., 2017). The Rio Cordon stream has developed its torrential system mainly over quaternary moraine and scree deposits. The average slope of the main channel is $17 \%$, featuring a rough streambed with step-pool morphology and large boulders. The grain size distribution of surface material exhibits the percentiles $D_{16} / D_{50} / D_{84}$ equal to $29 / 114 / 358 \mathrm{~mm}$, respectively. Currently, the streambed is strongly armoured with the subsurface $D_{50}(38 \mathrm{~mm})$ three-fold lower in respect to the surface $D_{50}$ (Mao et al., 2010). The bankfull discharge was estimated by Lenzi et al. (2006) as equal to $2.30 \mathrm{~m}^{3} \mathrm{~s}^{-1}$. 
141 In terms of land use, alpine grasslands and shrubs cover $60 \%$ and $15 \%$ of the basin area, respectively. Non-

142 vegetated areas and bare rocks (i.e. subvertical cliffs) are present in $14 \%$ of the catchment, while the forested 143 areas (Picea abies and Larix decidua) cover only the lower part, accounting for 6\%. Anthropogenic 144 influences are limited to a small number of hikers and seasonal grazing of bovine, donkeys, and sheep. Also, 145 a total absence of artificial structures can be observed along the river network.

\section{Climate data}

148 In the Rio Cordon basin, two meteorological stations were set up by the Veneto Region (Experimental 149 Centre of Arabba) and currently managed by ARPA Veneto. In 1986, at 1,763 m.a.sl., the Rio Cordon station 150 was established. Here, rainfall is continuously gathered by a heated rain gauge, while air temperature, 151 atmospheric pressure, relative humidity, and solar radiation have been constantly recorded since 1994. An 152 additional meteorological station (Mondeval di Sopra station) equipped with a rain gauge and an air 153 temperature sensor was established in 1992 at 2,130 m.a.sl. Climatic conditions are recorded hourly at both 154 stations. This continuous monitoring provides a detailed description of the rainfall regime for the last three 155 decades in the basin. For the aim of this paper the time series produced by the heated rain gauge installed in 156 the Rio Cordon station was used because it covers the entire period analyzed (i.e. 1986-2015). In relation to 157 the air temperature regime, the two meteorological stations located in the basin do not provide data over the 158 entire 1986-2015 period. In fact, the Mondeval di Sopra and Rio Cordon stations started to measure air 159 temperature in 1992 and 1994, respectively. To address this issue, the temperature time series produced for 160 Caprile was investigated. The Caprile meteorological station (ARPA Veneto) is located only $6 \mathrm{~km}$ south161 west of the Rio Cordon basin, at 1,008 m.a.s.l. (Figure 1a). The Caprile time series was used since it is the 162 closest meteorological station with continuous climate monitoring during the period 1986-2015.

\section{Sediment sources data}

165 During the 1986-2015 period, three inventories of potential sediment sources were created in the Rio Cordon 166 basin. These investigations were carried out by a collaboration between University of Padova and CNR-IRPI 167 that aimed to characterize the sources in terms of spatial extent, type, and location. The first inventory is 168 dated summer 1994 and is based both on geomorphic field surveys, performed using measuring tape and 
altimeter, and on interpretation of aerial photographs (1: 25,000 scale). The resulting inventory map $(1: 10,000$ scale) was later integrated in to a GIS environment to permit comparison with subsequent inventories (Cavalli et al., 2016).

172 The second inventory was carried out in late summer 2006 (Cavalli et al., 2016). First, the sediment sources 173 characterization was performed through geomorphic field mapping with a hand-held GPS receiver, laser 174 rangefinder, measuring tape, and digital photo camera. Additionally, in October 2006 a LiDAR flight was 175 carried out to produce a Digital Terrain Model (DTM). The high resolution (1 m) enabled investigation and mapping of sources not detected in the field due to their non-accessible location.

The most recent inventory was produced in 2016. Similar to the previous inventories, the 2016 mapping was started by field surveys performed with a GPS. To identify sediment sources located in unreachable areas photo interpretation was conducted on images derived by Bing ${ }^{\circledR}$ satellite service and WMS service for AGEA (i.e. Italian Agricultural Payments Agency). In both cases the images used are from 2012, but the absence of significant variations in the unreachable areas has permitted use of the images in the 2016 inventory.

183 Over the three inventories, the source areas were geometrically surveyed (without any evaluation of 184 thickness) and classified into seven types (Figure 2):

- debris flow-channel: all channels affected by debris flow (Figure 2a). Even triggering areas, if not clearly

- debris flow-deposit: depositional areas related to debris flow events (Figure 2a). A mud-flow deposit

190 (Figure 2b) derived from a landslide of fine-medium grain size material (Figure 2f) occurred during the attributable to other processes (e.g. shallow landslides), were classified in this source type. Due to the access limitations of steep channels in which debris flow processes occur, the geometry of this sediment source type was approximately mapped in the field; 
197 slopes and anthropic causes, particularly the intensive cattle grazing that leads to the progressive grass

198 cover degradation;

199 - eroded stream bank: channel network banks presenting erosion, mainly triggered by the water flow 200 (Figure 2d). The distinction between eroded stream bank and erosional area is justified by the great 201 importance for sediment dynamics played by sources belonging to the former type and due to their direct 202 link with the channel network;

- landslide: steep debris-mantled slope where the action of gravity is the primary driving force. All the 204 detected landslides initiated in sediment (Figure 2f);

- rockfall deposit: depositional areas related to rockfall events;

- active talus: sediment eroded from rock cliffs temporarily stored as scree deposits on talus slopes (Figure 2g).

Moreover, small wetlands areas (Figure $2 \mathrm{~h}$ ) which display an important role in the deposition and entrapment of sediments were also surveyed but not considered as sediment sources.

Further details on the Rio Cordon inventories and on the methodology used can be found in Cavalli et al. (2016) and Ferrato et al. (2017).

\section{Sediment connectivity}

In order to depict spatial patterns of sediment connectivity in the catchment, a topography-based index of sediment connectivity (IC) (Cavalli et al., 2013) was applied. In this work the index, expressing the potential connection between hillslope and selected targets, is aimed at evaluating the potential linkage between the hillslope domain and basin outlet. IC was computed through SedInConnect 2.0 (Crema et al., 2015) using a LiDAR-derived DTM at $1 \mathrm{~m}$ resolution (Cavalli et al., 2016) and a weighting factor based on surface roughness. Further details on the methodology can be found in Cavalli et al. (2013).

\section{Fluvial sediment fluxes data}

In the Rio Cordon basin, the fluvial sediment fluxes have been continuously recorded since 1986 by a longterm monitoring program. The program was established through a collaboration between University of 
Padova and Veneto Region which in 1985 led to the construction of a permanent monitoring station designed for the continuous measurement of water discharge $(Q)$, suspended sediment load $(S S L)$ and bedload $(B L)$. Located at 1,763 m.a.s.l. (i.e. basin outlet), the monitoring station measures $Q$ by two water gauges and a sharp-crested weir, while SSL is assessed by two turbidimeters. Specifically, the sampling time resolution is 1-hour during ordinary flow conditions $\left(Q<1 \mathrm{~m}^{3} \mathrm{~s}^{-1}\right)$, and increases to 5 minutes for $Q>1 \mathrm{~m}^{3} \mathrm{~s}^{-1}$. In the period 1986-2015, a time fraction of $15 \%$ presented data gaps in relation to the water discharge or suspended load. An inclined metallic grid enables the coarse material $(D>20 \mathrm{~mm})$ of bedload events to be separated from the water flow. Once separated, the bedload falls into a storage area where 24 ultrasonic sensors measure the transport rate. To achieve a higher estimation accuracy, since 2012 a Terrestrial Laser Scanner has been used to estimate the amount of coarse material deposited in the storage area. The volume data obtained is then converted to mass using a sediment density of $2.65 \mathrm{Mg} \mathrm{m}^{3}$ and a material porosity of $35 \%$. In relation to the cause-effect coupling between climate forcing and sediment delivery patterns, the research activities performed in the Rio Cordon alpine basin led to the availability of a quasi-unique dataset. Overall, the dataset (1986-2015) permits the investigation of sediment source response (i.e. sediment source data) to long-term climate trends (i.e. climate data). In turn, it is possible to analyze whether, and how, the trends of climatic condition and evolution of sediment source areas cause a response in fluvial sediment fluxes (i.e. fluvial sediment fluxes data).

\section{RESULTS}

\section{Climate trends}

The trends of the monthly average air temperature recorded by the Caprile (1,008 m.a.s.1.), Rio Cordon (1,763 m.a.s.1.) and Mondeval di Sopra (2,130 m.a.s.l.) meteorological stations during 2011-2015 (Figure 3a) show the presence of an elevation gradient. The temperature shifts that occurred in the Rio Cordon basin appear to be well described by the Caprile station. Comparing the hourly temperatures recorded in the 20112015 period a roughly linear relationship can be observed between the temperature recorded by the Caprile station and the Rio Cordon and Mondeval di Sopra measurements (Figure 3b). According to the Pearson correlation coefficients $(r)$, Rio Cordon and Caprile temperatures were strongly correlated $(r=0.96, p<$ 0.01). A significant correlation $(r=0.92, p<0.01)$ also exists between Mondeval di Sopra and Caprile. 
253 Therefore, due to the absence of a long-term temperature time series record in the Rio Cordon basin, the

254 Caprile dataset was used in this study as it covers the study period.

255 \#\#\#\#\#\# Figure 3 \#\#\#\#\#\#

256 The mean annual air temperature for Caprile over the $1986-2015$ period is $6.9{ }^{\circ} \mathrm{C}$ (Table 1$)$. The trend of 257 mean annual temperature as deviation from the 1986-2015 average (i.e. annual temperature anomaly) seems 258 to suggest the occurrence of three distinct stages during the study period. Initially, between 1986 and 1991 , 259 the temperature constantly exhibits a negative anomaly, with annual averages lower than the 30 -year average 260 (Figure 4). In the period 1986-1991, the mean temperature $\left(6.5^{\circ} \mathrm{C}\right)$ was clearly lower than the $1986-2015$ 261 average, with the coldest year recorded in 1991 with an anomaly of $-0.7^{\circ} \mathrm{C}$ (i.e. mean annual $=6.2^{\circ} \mathrm{C}$ ). \#\#\#\#\#\#\# Figure 4 \#\#\#\#\#\#\#

Since 1992, the temperature regime was characterized by a high inter-annual variability with a succession of positive and negative anomalies that lasted until 2006. In this period, the warmest year was recorded in 1994 with a temperature anomaly of $+0.4^{\circ} \mathrm{C}$. On the other hand, the highest negative anomaly equal to $-0.8^{\circ} \mathrm{C}$ (i.e. mean annual $=6.1{ }^{\circ} \mathrm{C}$ ) was measured both in 1995 and 2005. Such years were the coldest of the last 30 years. Since 2007, the mean annual temperatures were constantly above the 1986-2015 average, with an increase in positive anomalies (Figure 4). The only exception to this trend was 2010 , with a negative anomaly of $-0.4{ }^{\circ} \mathrm{C}$. From 2007 the mean temperature was $7.3{ }^{\circ} \mathrm{C}$, corresponding to an increase of $5.8 \%$ in respect to the 1986 2015 average. Also, in 2015 the highest temperature of the whole 1986-2015 period was recorded, with a 271 positive anomaly equal to $+1.1^{\circ} \mathrm{C}$.

Rainfall recorded by the Rio Cordon meteorological station shows that between 1986 and 1999 the annual precipitation was relatively constant, with limited inter-annual variability (Figure 5). Since 2000, significant shifts in the precipitation regime were observed. In 2000, 2001 and 2002 annual precipitation was recorded as 1,409 mm, $949 \mathrm{~mm}$ and 1,358 mm, respectively (Table 1). These amounts clearly differ from each other and from the 1986-2015 average (i.e. $1,157 \mathrm{~mm} /$ year). From 2003 to 2006 a period characterized by an 278 almost constant significant reduction in rainfall was observed. During this 4-year period the average 279 precipitation was $942 \mathrm{~mm}$, and $2004(841 \mathrm{~mm})$ was the driest year of the last three decades. Since 2007 a 280 long period of increased precipitation was recorded. Particularly, the mean annual precipitation between 
2007 and 2015 was $1392 \mathrm{~mm}, 20 \%$ higher than the 1986-2015 average. The wettest year of the entire study period was $2014(1,757 \mathrm{~mm}$ ) (Table 1). The increase observed since 2007 was partially offset by 2015 , when the annual rainfall was $1,015 \mathrm{~mm}$.

\section{\#\#\#\#\#\# Figure 5 \#\#\#\#\#\#}

\section{Trend of hillslope sediment sources}

In 1994, 292 sources were detected, covering a total area of 498,265 $\mathrm{m}^{2}$, with an average extent of 1,706 $\mathrm{m}^{2}$. In terms of extent, active talus slopes $\left(174,423 \mathrm{~m}^{2}\right)$ was the predominant source type. In 1994, the 24 mapped talus areas exhibited an average surface area of $7,268 \mathrm{~m}^{2}$ and were detected mainly at the foot of the subvertical cliffs located in the upper part of the basin (Figure 6). Erosional areas were also particularly vast $\left(160,241 \mathrm{~m}^{2}\right)$, with an average extent $\left(2,428 \mathrm{~m}^{2}\right)$ notably lower than the active talus. More than 160 landslides were identified in the basin by the 1994-inventory, extending over a total area of $149,197 \mathrm{~m}^{2}$ (Table 2). Compared with these source types, the areas affected by stream bank erosion and debris flow (channels and deposits) were approximately two orders of magnitude lower, covering $5,517 \mathrm{~m}^{2}$ and $8,887 \mathrm{~m}^{2}$, respectively. Overall, in 1994 the active source areas covered $9.9 \%$ of the basin surface. Additionally, 13 wetlands, extending on average $3,588 \mathrm{~m}^{2}$, were detected (Table 2).

\section{\#\#\#\#\#\# Table 2 \#\#\#\#\#\#}

On the other hand, in 2006, more than 400 source areas were identified, covering $648,554 \mathrm{~m}^{2}$. The average area $\left(1,548 \mathrm{~m}^{2}\right)$ slightly decreased from 1994 . As in the first inventory, the largest source type in 2006 was active talus, which are mainly located in the upper part of the basin (Figure 6). The 26 active talus exhibited an average area $\left(8,084 \mathrm{~m}^{2}\right)$ larger than in the previous inventory. More than 190 landslides were mapped in 2006, with several new sources activated along the left side of the lower basin (i.e. South-Southeast). In this inventory, the landslides showed an average surface area comparable to that observed in 1994. In total, this source type accounted for a surface area of $191,797 \mathrm{~m}^{2}$. Erosional area covers a similar areal extent, but this type was characterized by larger individual sources (average area $=1,745 \mathrm{~m}^{2}$ ). However, compared to the results obtained in 1994, erosional area is less extensive (- 39\%). Since the 2006-inventory, debris flowchannels and -deposits were separately mapped (Table 2). This classification highlighted that, with respect to debris flow-channels, debris flow-deposits were larger both in terms of total and average area. Overall, 78 
309 source areas were related to debris flow processes, covering an area (71,623 $\left.\mathrm{m}^{2}\right)$ clearly higher than in 1994.

310 Such an increase is not evident in the average area, which remains similar to that observed in the previous 311 inventory. Also in 2006, eroded stream bank was observed in the lower extent of the basin $\left(3,902 \mathrm{~m}^{2}\right)$, with

31222 sediment sources covering on average just $177 \mathrm{~m}^{2}$. Overall, in 2006 the active source areas covered $12.9 \%$

313 of catchment area. Total and average area of wetlands was fully comparable to that observed in 1994 (Table $3142)$.

315 Finally, the source area inventory performed in 2016 showed an extent comparable to 2006. Despite a slight 316 decrease in the average area (-4\%), the active talus remained the main source type. In 2016, a considerable 317 portion of the basin remains affected by landslides, which slightly increased in total area $(+2 \%)$ while 318 decreased in average surface area (-5\%). An opposite trend can be observed in the erosional area. Compared 319 to 2006, debris flow-channels and debris flow-deposits showed a different evolution. In fact, the debris flow320 channels increased both in terms of total $(+23 \%)$ and average area $(+17 \%)$, while debris-flow deposits 321 decreased in both. Notably, eroded stream bank reduced in extent, with the average area nearly two fold 322 lower compared to 2006. Interestingly, in 2016 a massive rockfall deposit $\left(20,676 \mathrm{~m}^{2}\right)$ was detected along 323 the northeastern cliffs (Figure 6). The deposit obliterated more than $10,000 \mathrm{~m}^{2}$ of previously classified active 324 talus (Table 2). Overall, during this last period the extent of the catchment covered by sediment source areas 325 remains exactly the same. Similarly, the wetlands exhibited only a slight reduction in terms of average area ($3268 \%)$.

327 In general, it should be noted that the 1994 sediment source database is characterized by a lower accuracy 328 and completeness with respect to the most recent ones. Accordingly, the comparative quantitative analysis 329 with the 2006 and 2016 databases needs to be carried out in a critical manner, as reported in Cavalli et al. 330 (2016).

\section{Sediment connectivity analysis}

334 The map of IC highlighting the potential degree of linkage between hillslope and catchment outlet is 335 presented in Figure 7. This analysis highlights that high connectivity values characterize the lower sector of the catchment, which is characterized by steep slopes and a narrow valley. In this part of the basin, most of 
the sediment sources on hillslopes can be considered well connected to the outlet. Different spatial patterns of connectivity can be observed in the middle and upper parts of the study area. Lower IC values suggest that the low-gradient belt and several depressions characterizing the middle part of the basin strongly affect the sediment fluxes, favoring deposition and retainment of sediment and, thus, decoupling sediment sources located in these areas from the outlet.

\section{\#\#\#\#\#\# Figure 7 \#\#\#\#\#\#}

\section{Fluvial sediment fluxes trends}

The long lasting monitoring of fluvial sediment transport in the Rio Cordon enables us to assess the sediment fluxes which occurred during the last 30 years. During the period $1986-2015$, a total of $15,110 \mathrm{Mg}$ was exported from the basin to the monitoring station as suspended sediment load and bedload (Figure 8). The total load recorded corresponds to an annual sediment yield equal to $504 \mathrm{Mg} \mathrm{yr}^{-1}$ (i.e. $100 \mathrm{t} \mathrm{km}^{-2} \mathrm{yr}^{-1}$ ). \#\#\#\#\#\# Figure 8 \#\#\#\#\#\#

Overall, during the study period the suspended load fraction $\left(S S L_{f}=0.79\right)$ clearly prevails over the bedload fraction $\left(B L_{f}=0.21\right)$. In terms of temporal trends, the sediment yield reflects the high inter-annual variability exhibited by suspended load and bedload. Between 1986 and 1993, the annual sediment yield was continuously lower than $1,000 \mathrm{Mg} \mathrm{yr}^{-1}$, except in 1991, with $S S L_{f}$ always above 0.60 . As a consequence of the September 1994 exceptional event, more than 4,000 t were exported from the basin in 1994. In this year, bedload (1,543 t) and suspended load (2,524 t) exhibited the highest magnitude ever recorded. Between 1994 and 2003, significant fluctuations can be observed in the sediment fluxes (Figure 8), with the annual sediment yield varying by two orders of magnitude. Specifically, the annual sediment export at the monitoring station ranged between $12 \mathrm{t}$ recorded in 2003 to 1,743 $\mathrm{t}$ assessed in 2001. Large annual shifts can be observed also in the partitioning, with $S S L_{f}$ varying from 0.59 to 1.00 recorded in 1998 and 1997, respectively. Since 2003, the annual sediment yields were consistently lower than $600 \mathrm{Mg} \mathrm{yr}^{-1}$. In the last 13 years an evident decrease of bedload yield was observed with magnitude constantly $<100 \mathrm{Mg} \mathrm{yr}^{-1}$ and $B L_{f}<$ 0.30. A minor interruption to this trend was recorded in $2014\left(B L_{f}=0.31\right)$, when $118 \mathrm{t}$ of coarse material were exported from the basin. 


\section{DISCUSSION}

366 Despite the high complexity of the mountain system and the complex interplay of different controlling 367 factors (i.e. topography, runoff, sediment availability), the availability of the quasi-unique dataset provided by the Rio Cordon monitoring program permits us to assess the cause-effect coupling between climate forcing and sediment delivery patterns. Specifically, the continuous measurement of climatic conditions and sediment fluxes were analyzed in combination with the three sediment source inventories representative of sediment availability in the basin in the last 30 years. The analysis focused on the trends exhibited during the inter-periods, i.e. 1986-1993, 1994-2006 and 2007-2015. In the Rio Cordon, the climate and fluvial sediment flux datasets are generally of good quality since they are produced by monitoring stations constantly managed by ARPA Veneto (Rainato et al., 2017). Between 1986 and 1993, the climatic conditions appear relatively stable both in terms of temperature and rainfall. During this period the mean temperature was 6.6 ${ }^{\circ} \mathrm{C}$, with the standard deviation $\left(S D=0.30{ }^{\circ} \mathrm{C}\right)$ of the annual values confirming that no significant fluctuations occurred. Likewise, rainfall exhibited a low inter-annual variability $(S D=136 \mathrm{~mm})$, with an average precipitation equal to $1,063 \mathrm{~mm}$. Similar to what was observed in the small and formerly glaciated Val Müschauns (Swiss Alps) by Messenzehl et al. (2014), the sediment source area inventories in the Rio Cordon are generally dominated by active talus, erosional area and landslides. In 1994, the sources appeared altogether quite distant from the channel network (Figure 6). Fluvial sediment fluxes showed a stable trend during the 1986-1993 period, similar to the trend exhibited by the climatic conditions. The mean annual sediment yield was $339 \mathrm{Mg} \mathrm{yr}^{-1}$, with clear prevalence of $S S L$ fraction $\left(S S L_{f}=0.85\right)$. Climatically, the 19942006 period was somewhat similar to the 1986-1993 period, but exhibited larger inter-annual fluctuations. Indeed, the average temperature $\left(6.7^{\circ} \mathrm{C}\right)$ was in line with that observed in the previous phase, while $S D$ increased to $0.44{ }^{\circ} \mathrm{C}$. The same trend can be observed in precipitation, with mean and $S D$ equal to $1,053 \mathrm{~mm}$ and $190 \mathrm{~mm}$, respectively. In addition to the climatic conditions, during the period 1994-2006 source area change was strongly affected by the occurrence of high magnitude/low frequency flood events. Particularly, the September 1994 exceptional event strongly impacted the Rio Cordon basin, creating new source areas and reactivating old ones (Rainato et al., 2017), while in May 2001 a large mudflow occurred along a small tributary located in the lower part of the basin, creating an extended debris fan $\left(\sim 4,176 \mathrm{~m}^{3}\right)$ (Lenzi et al., 2004). The 2006 source inventory showed a noticeable increase $(+30 \%)$ in terms of total area. This change 
is affected by a certain degree of uncertainty, due to the use of geomorphic field mapping to characterize the sediment sources and, particularly, by the different methodology used in the 2006 inventory survey compared to the 1994 survey (Cavalli et al., 2016). As argued by several authors (Bishop et al., 2012; Messenzehl et al., 2014), field mapping is subject to a certain error range, rarely computed, and mainly due to the subjectivity and the uncertainty derived by time-consuming field operations. Nevertheless, geomorphic field mapping is largely used to investigate sediment cascades in mountain environments, enabling researchers to obtain qualitative results scarcely achieved by quantitative approaches (Messenzehl et al., 2014). The effect of using a diverse methodology between 1994 and 2006 is clearly evident in the number of sources detected and in the total area (Table 2). Principally, the increase observed is due to the higher accuracy used to describe the debris flow type $\left(+62,736 \mathrm{~m}^{2}\right)$. Nevertheless, a certain increase in this type seems to have occurred, as suggested by the increased average surface. Interestingly, the climatic fluctuations and the high magnitude/low frequency floods increased the number, extent, and average area of landslides. Such variation is particularly evident in the lower part of the basin along the slopes next to the channel network (Figure 6). Compared to that noted in 1994, in 2006 a higher number of erosional areas was observed along the hillslopes, but they were smaller on average (Figure 6). This evolution could be explained by climate forcing between 1994-2006, or by extensive cattle grazing occurring in the catchment (Cavalli et al., 2016). Notwithstanding the high magnitude/low frequency floods, eroded stream bank was reduced compared to 1994 . This decrease seems to suggest that the channel network rapidly exhausted the sediment availability here created by the high magnitude events. In 12 years (1994-2006), eroded stream bank was stabilized or reduced by supplying and increasing the transport efficiency of the post-September 1994 floods (Rainato et al., 2017). In the 1994-2006 period, the partitioning $\left(B L_{f}=0.15\right)$ was fully comparable to that observed in the 1986-1993 period. In this sense, the increase of active talus and landslides did not lead to a variation in the $B L$ and $S S L$ fractions. The partitioning clearly varied only in the years with high magnitude/low frequency floods such as $1994\left(B L_{f}=0.38\right), 1998\left(B L_{f}=0.41\right)$, and $1999\left(B L_{f}=0.31\right)$, i.e.

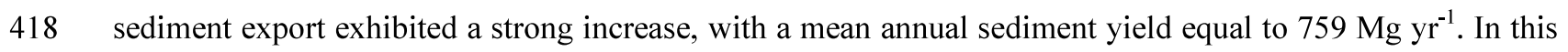

419 sense, the key role played by the exceptional September 1994 flood is evident. However, sediment export 420 remains high (i.e. $484 \mathrm{Mg} \mathrm{yr}^{-1}$ ) even excluding 1994 from the analysis. The shifts observed in the climatic 
conditions and the relative change of sediment source areas seems to only partially explain the augmented

422

423

424

425

426

427

428

429

430

431

432

433

434

435

436

437

438

439

440

441

442

443

444

445

446

447

448

sediment export measured in the 1994-2006 period, stressing the role played by the in-channel sediment availability resulting from the removal of the armour layer and bedforms by the September 1994 flood.

The 2007-2015 period showed an evident increase both in terms of average temperature $\left(7.3^{\circ} \mathrm{C}\right)$ and mean precipitation $(1,392 \mathrm{~mm})$. This increasing trend appears to be more stable in the temperature data, exhibiting an inter-annual variability $\left(S D=0.48{ }^{\circ} \mathrm{C}\right)$ in line with that observed in the 1994-2006 period. On the other hand, precipitation was characterized by significant annual fluctuations $(S D=256 \mathrm{~mm})$. This climate forcing resulted in a very limited sediment source change. The number of landslides increased slightly, while the decreased extent of active talus was mainly due to the effect of the 2016 rockfall, which obliterated $\sim 10,000$ $\mathrm{m}^{2}$ previously classified as active talus (Table 2). In addition to the climatic conditions, cattle grazing concentrated in specific areas of the basin could explain the variation in erosional area, which decreased in total count (-15\%) but increased in average area. In the period 2007-2015, the increased precipitation was not accompanied by an intensification of flood occurrence, which may explain the reduction observed in eroded stream bank compared to the 1994-2006 period. The decrease of fluvial bedload fraction $\left(B L_{f}=0.07\right)$ seems to somehow reflect this sediment source evolution. Generally, the climatic trend recorded in the 2007-2015 period did not produce an increase in erosion processes in the Rio Cordon basin. This hypothesis also seems to be supported by the increase in stabilized areas and by the reduction of small wetlands (Table 2). The absence of a significant change of sediment source areas due to climate forcing, combined with the armoring of the channel network, seems to explain the significant decrease observed in sediment export during the 2007-2015 period, when the mean annual sediment yield was $237 \mathrm{Mg} \mathrm{yr}^{-1}$. Compared to glaciated basins, non-glacial catchments usually exhibit lower erosion rates but higher sediment exports due to confined valley morphology and, hence, by the high transport efficiency of the stream (Hinderer, 2001; Mao et al., 2009). Notwithstanding the unglaciated nature of the Rio Cordon basin, the sediment fluxes were generally limited, stressing the key role played by the evident sediment disconnectivity (Figure 7). Particularly, the upper part of the basin is clearly decoupled from the outlet, reducing the potential contribution of active talus, i.e. the dominant source type. Overall, a large number of current sediment sources are located away from the channel network, in areas not usually coupled to the main channel (Figure 6). A comparable degree of sediment disconnectivity is normally observed in glaciated alpine basins due to the presence of hanging 
valleys or inherited glacial landforms (Cavalli et al., 2013; Heckmann \& Schwanghart, 2013; Messenzehl et al., 2014; Micheletti \& Lane, 2016). In the Rio Cordon basin, the low-gradient belt located at 2,200 m.a.s.1 acts as the main buffer within the sediment cascade continuity. Consequently, the current state of disconnectivity appears quite stable in time, since it is imposed by steady geomorphic conditions. As 453 demonstrated by several authors (Messenzehl et al., 2014, Micheletti et al., 2015) the presence of a buffer 454 within the sediment cascade makes it difficult to fully comprehend the consequence of recent climate change on sediment fluxes. In this sense, the effect of decoupling between sediment sources and the channel network was clearly observed in the period 2007-2015, when the increase in temperature and precipitation was not reflected by an intensification of sediment export. Clear evidence of this scenario was also the rockfall which occurred in 2016, affecting a large surface and mobilizing massive amounts of material, but not resulting in any effects in terms of fluvial sediment fluxes. Moreover, a high transport efficiency was achieved only recently in 2012 and 2014 when floods supported by an effective hillslope-channel network coupling occurred (Rainato et al., in press). In light of ongoing climate change, it will be interesting to assess how long this disconnected status will last. The potential change induced by the climate on erosion processes (Stott \& Mount, 2007) could lead to an enhanced sediment cascade condition and, in turn, to a lagged and massive response of the basin (Messenzehl et al., 2014).

\section{FINAL REMARKS}

This study investigated the climate trends, the relative sediment source areas evolution, and the fluvial sediment export response exhibited by an alpine basin over the last three decades. The research activities performed in the Rio Cordon basin led to the availability of a quasi-unique dataset based on the continuous measurement of temperature, precipitation, fluvial sediment fluxes, and three sediment source inventories established in 1994, 2006, and 2016. The analysis focused on the trends exhibited during the periods 19861993, 1994-2006, and 2007-2015. In terms of climatic conditions, three distinct climate forcing stages can be observed in the periods analyzed: a relatively stable phase (1986-1993), a period characterized by temperature and rainfall fluctuations (1994-2006), and a more recent warmer and wetter phase (2007-2015). In the 1986-1993 period, the fluvial sediment fluxes reflected the stable trend exhibited by the climatic conditions. In the subsequent 1994-2006 period, the average temperature and precipitation were in line with 
477 that previously observed, although with higher inter-annual variability. Notwithstanding the climate forcing

478 and the occurrence of high magnitude/low frequency floods that strongly influenced the source areas, 479 between 1994 and 2006 the Rio Cordon basin showed relatively limited erosion activity. Hence, the climatic 480 conditions and the change in sediment source areas can only partially explain the significant increase in 481 sediment export recorded in the 1994-2006 period. In this sense, the sediment availability resulting from 482 armour layer and bedform removal appears crucial to describing the sediment fluxes during this period, 483 stressing the key role of in-channel sediment supply. In the recent period 2007-2015 a marked climate 484 warming accompanied by increased precipitation was observed. This climate forcing did not affect the evolution of sediment landforms, with sediment source extent remaining similar between 2006 and 2016 .

486 The absence of a significant response from sediment source areas and the restoration of the channel armour 487 layer can describe the limited sediment fluxes observed during the last decade. In particular, the increased

488

489

490

491

492

493

494

495

496

497

498

499

500

501

502

503

504 temperature and precipitation were not accompanied by an increase in flood occurrence and magnitude, stressing the evident sediment disconnectivity. In the Rio Cordon, as in similar mountain basins, it will be interesting to monitor and investigate how long the current (dis)connectivity status will be maintained, particularly in light of climate change, that could rapidly alter the sediment dynamics observed so far.

In this work, the results suggest a nonlinear behavior between climatic condition, landform response and sediment dynamics, emphasizing the high complexity of the mountain systems. Very few unglaciated mountain basins are instrumented to investigate contemporary climate trends, the change of sediment source areas, and sediment export. As a result, quantitative long-term data are particularly rare. The quasi-unique monitoring program maintained in the Rio Cordon basin since 1986 enabled us to analyze whether, and how, the trends of climatic condition and sediment landform evolution can influence fluvial sediment fluxes, stressing the role played by the presence/absence of hillslope-channel connectivity and shedding further light on the complex sediment delivery processes acting in mountain basins.

\section{ACKNOWLEDGEMENTS}

This research was funded by the University of Padova Research Projects 'Sediment transfer processes in an Alpine basin: sediment cascades from hillslopes to the channel network-BIRD167919', and "Source areas 
505 and channel networks. Increasing the knowledge on sediment connectivity around alpine basins"

506 DOR1701834/17. We would like to thank Prof. Mario Aristide Lenzi since the article has benefited from

507 discussion with him, as well as Matteo Cesca (ARPA Veneto) for the technical support. Many thanks go to

508 Alison Garside for revising the English. We are grateful to Karoline Messenzehl and David Morche for their 509 constructive comments, which helped us to improve the manuscript.

510

511

512

513

514

\section{REFERENCES}

Ashmore PE, Church M. 2001. The impact of climate change on rivers and river processes in Canada. Bulletin of the Geological Survey of Canada 555: 1-48.

Baewert H, Morche D. 2014. Coarse sediment dynamics in a proglacial fluvial system (Fagge River, Tyrol). Geomorphology 218: 88-97.

Bennett G, Molnar P, McArdell B, Schlunegger F, Burlando P. 2013. Patterns and controls of sediment production, transfer and yield in the Illgraben. Geomorphology 188: 68-82.

Bennett G, Molnar P, McArdell B, Burlando P. 2014. A probabilistic sediment cascade model of sediment production, transfer and yield in the Illgraben. Water Resources Research 50: 1225-1244. DOI: 10.1002/2013WR013806.

Bishop MP, James LA, Shroder Jr JF, Walsh SJ. 2012. Geospatial technologies and digital geomorphological mapping: Concepts, issues and research. Geomorphology 137: 5-26.

Bocchiola D. 2014. Long term (1921-2011) changes of Alpine catchments regime in Northern Italy. Advances in Water Resources 70: 51-64. 
533 Bracken LJ, Turnbull L, Wainwright J, Bogaart P. 2015. Sediment connectivity: a framework for 534 nderstanding sediment transfer at multiple scales. Earth Surface Processes and Landforms 40: 177-188. 535 DOI: $10.1002 /$ esp.3635, 2015.

536

537 Buendia C, Vericat D, Batalla RJ, Gibbins CN. 2016. Temporal dynamics of sediment transport and transient 538 in-channel storage in a highly erodible catchment. Land Degradation \& Development 27: 1045-1063. DOI: $539 \quad 10.1002 / 1 d r .2348$.

540

541 Carrivick JL, Chase SE. 2011. Spatial and temporal variability in the net mass balance of glaciers in the 542 southern Alps, New zealand. New Zealand Journal of Geography and Geophysics 54: 415-429.

543

544

545

546

547

548

549

550

551

552

553

554

555

556 557

558

559

560

Cavalli M, Trevisani S, Comiti F, Marchi L. 2013. Geomorphometric assessment of spatial sediment connectivity in small Alpine catchments. Geomorphology 188, 31-41.

Cavalli M, Tarolli P, Dalla Fontana G, Marchi L. 2016. Multi-temporal analysis of sediment source areas and sediment connectivity in the Rio Cordon catchment (Dolomites). Rendiconti Online Società Geologica Italiana 39, 27-30.

Cavalli M, Goldin B, Comiti F, Brardinoni F, Marchi L. 2017. Assessment of erosion and deposition in steep mountain basins by differencing sequential digital terrain models. Geomorphology 291, 4-16. DOI: 10.1016/j.geomorph.2016.04.009

Comiti F, Da Canal M, Surian N, Mao L, Picco L, Lenzi MA. 2011. Channel adjustments and vegetation cover dynamics in a large gravel bed river over the last 200 years. Geomorphology 125: 147-159.

Crema S, Schenato L, Goldin B, Marchi L, Cavalli M. 2015. Toward the development of a stand-alone application for the assessment of sediment connectivity. Rendiconti Online della Società Geologica Italiana 34, 58-61. 
562 Dalla Fontana G, Marchi L. 2003. Slope-area relationships and sediment dynamics in two alpine streams. 563 Hydrological Processes 17(1): 73-87.

564

565 Dell'Agnese A, Brardinoni F, Toro M, Mao L, Engel M, Comiti F. 2015. Bedload transport in a formerly 566 glaciated mountain catchment constrained by particle tracking, Earth Surface Dynamics 3: 527-542. DOI: 567 10.5194/esurf-3-527-2015, 2015.

568

569

Ferrato C, De Marco J, Tarolli P, Cavalli M. 2017. An updated source areas inventory in the Rio Cordon catchment (Dolomites). Rendiconti Online Società Geologica Italiana.

Fischer M, Huss M, Hoelzle M. 2014. Surface elevation and mass changes of all Swiss glaciers 1980-2010. Cryosphere Discussions 8: 4581-4617.

574

575 Geilhausen M, Morche D, Otto JC, Schrott L. 2013. Sediment discharge from the proglacial zone of a retreating Alpine glacier. Zeitschrift für Geomorphologie 57: 29-53.

Harden CP, Scruggs PD. 2003. Infiltration on mountain slopes: A comparison of three environments.

Heckmann T, Schwanghart W. 2013. Geomorphic coupling and sediment connectivity in an alpine catchment - Exploring sediment cascades using graph theory. Geomorphology 182: 89-103. DOI: 10.1016/j.geomorph.2012.10.033.

Hinderer M. 2001. Late Quaternary denudation of the Alps, valley and lake fillings and modern river loads. Geodinamica Acta 14, 231-263. 
588 Hinderer M, Kastowski M, Kamelger A, Bartolini C, Schlunegger C. 2013. River loads and modern 589 denudation of the Alps - a review. Earth-Science Reviews 118: 11-44.

590

591 Hirabayashi Y, Mahendran R, Koirala S, Konoshima L, Yamazaki D, Watanabe S, Kim H, Nakae S. 2013.

592 Global flood risk under climate change. Nature Climate Change 3: 816-821.

593

594 Jones AP. 2000. Late Quaternary sediment sources, storage and transfers within mountain basins using clast 595 lithological analysis: Pineta Basin, central Pyrenees, Spain. Geomorphology 34: 145-161.

596

597 Keesstra SD, van Huissteden J, Vandenberghe J, Dam OV, de Gier J, Pleizier ID. 2005. Evolution of the 598 morphology of the river Dragonja (SW Slovenia) due to land-use changes. Geomorphology 69: 191-207.

599

600

601

602

603

604

605

606

607

608

609

610

611

612

613

614

Lana-Ranault N, Regüés-Muñoz D, Martí-Bono CE, Beguería S, Latrón J, Nadal-Romero E, Serrano-Muela P, García-Ruiz JM. 2007. Temporal variability in the relationships between precipitation, discharge and suspended sediment concentration in a small Mediterranean mountain catchment. Nordic Hydrology 38: 139-150.

Lane SN, Bakker M, Gabbud C, Micheletti N, Saugy JN. 2017. Sediment export, transient landscape response and catchment-scale connectivity following rapid climate warming and Alpine glacier recession. Geomorphology 277, 210-227. DOI: 10.1016/j.geomorph.2016.02.015.

Le Pera E, Sorriso-Valvo M. 2000. Weathering, erosion and sediment composition in a high-gradient river, Calabria, Italy. Earth Surface Processes and Landforms 25: 277-292.

Lenzi MA, Mao L, Comiti F. 2003. Interannual variation of suspended sediment load and sediment yield in an alpine catchment. Hydrological Science Journal 48(6): 899-915. 
61

616

617

618

619

620

621 622

Lenzi MA, Mao L, Comiti F. 2004. Magnitude-frequency analysis of bed load data in an Alpine boulder bed stream. Water Resourced Research 40(7): 1-12.

Leopold LB. 1994. A view of the river. Harvard University Press: Cambridge (USA). 298 pp.

Liébault F, Gomez B, Page M, Marden M, Peacock D, Richard D, Trotter CM. 2005. Land-use change, sediment production and channel response in upland regions. River Research and Applications 21: 739-756.

López-Tarazón JA, Batalla RJ, Vericat D, Francke T. 2012. The sediment budget of a highly dynamic mesoscale catchment: the River Isábena. Geomorphology 138: 15-28.

Mao L, Cavalli M, Comiti F, Marchi L, Lenzi MA, Arattano M. 2009. Sediment transfer processes in two Alpine catchments of contrasting morphological settings. Journal of Hydrology 364(1-2): 88-98.

Mao L, Comiti F, Lenzi MA. 2010. Bedload dynamics in steep mountain rivers: insights from the Rio Cordon Experimental Station (Italian Alps). In: Gray, J.R., Laronne, J.B., Marr, J.D.G. (Eds.), Bedloadsurrogate Monitoring Technologies, U.S. Geological Survey Scientific Investigations Report 2010-5091: pp. $253-265$.

Menzel L, Burger G. 2002. Climate change scenarios and runoff response in the Mulde catchment (Southern Elbe, Germany). Journal of Hydrology 267 (1-2): 53-64.

Messenzehl K, Hoffmann T, Dikau R. 2014. Sediment connectivity in the high-alpine valley of Val Müschauns, Swiss National Park - linking geomorphic field mapping with geomorphometric modelling, Geomorphology 221: 215-229.

Michael A, Schmidt J, Enke W, Deutschlander T, Malitz G. 2005. Impact of expected increase in precipitation intensities on soil loss results of comparative model simulations. Catena 61 (2-3): 155-164. 
643

644 Micheletti N, Lane SN, Lambiel C. 2015. Investigating decadal scale geomorphic dynamics in an Alpine 645 mountain setting. Journal of Geophysical Research: Earth Surface 120: 2155-2175.

646

647 Micheletti N, Lane SN. 2016. Water yield and sediment export in small, partially glaciated Alpine 648 watersheds in a warming climate. Water Resources Research 52(6): 4924-4943. DOI: $649 \quad 10.1002 / 2016$ WR018774.

650

651 Milly PCD, Wetherald RT, Dunne KA, Delworth TL. 2002. Increasing risk of great floods in a changing 652 climate. Nature 415: 514-517.

653

654 Montgomery DR, Buffington JM. 1997. Channel-reach morphology in mountain drainage basins. Geol. Soc. 655 Am. Bull. 109: 596-611.

656

657 Morche D, Haas F, Baewert H, Heckmann T, Schmidt KH, Becht M. 2012. Sediment transport in the 658 proglacial Fagge River (Kaunertal/Austria). In: Collins, A.L., Golosov, V., Horowitz, A.J., Lu, X., Stone, 659 M., Walling, D.E., Zhang, X. (Eds.), Erosion and Sediment Yields in the Changing Environment. IAHS 660 Press Wallingford, IAHS Publication 356: 72-81.

661

662

Moretto J, Rigon E, Mao L, Picco L, Delai F, Lenzi AM. 2014. Channel adjustments and island dynamics in 663 the Brenta River (Italy) over the last 30 years. River Research and Applications 30: 719-732.

664

665 Nijssen B, O'Donnell G, Hamlet A, Lettenmaier D. 2001. Hydrologic sensitivity of global rivers to climate 666 change. Climatic Change 50 (1-2): 143-175.

667

668 Picco L, Sitzia T, Mao L, Comiti F, Lenzi MA. 2016. Linking riparian woody communities and 669 fluviomorphological characteristics in a regulated gravel-bed river (Piave river, Northern Italy). 670 Ecohydrology 9: 101-12. 
672 Piton G, Recking A. in press. The concept of travelling bedload and its consequences for bedload 673 computation in mountain streams. Earth Surface Processes and Landforms. DOI: 10.1002/esp.4105.

674

675 Rainato R, Mao L, Garcia-Rama A, Picco L, Cesca M, Vianello A, Preciso E, Scussel GR, Lenzi MA. 2017.

676 Three decades of monitoring in the Rio Cordon instrumented basin: sediment budget and temporal trend of 677 sediment yield. Geomorphology 291, 45-56. DOI: 10.1016/j.geomorph.2016.03.012.

678

679

Rainato R., Mao L., Picco L., in press. Near-bankfull floods in an Alpine stream: effects on the sediment 680 mobility and bedload magnitude. International Journal of Sediment Research. DOI: $681 \quad 10.1016 / j . i j s r c .2017 .03 .006$.

682

683

Recking A. 2012. Influence of sediment supply on mountain streams bedload transport. Geomorphology 175684 176: 139-150. DOI: 10.1016/j.geomorph.2012.07.005.

685

686

Rossi M, Witt A, Guzzetti F, Malamud BD, Peruccacci S. 2010. Analysis of historical landslides in the 687 Emilia-Romagna region, northern Italy. Earth Surface Processes and Landforms 35: 1123-1137.

688

Sanjuán Y, Gómez-Villar A, Nadal-Romero E, Álvarez-Martínez J, Arnáez J, Serrano-Muela MP. Rubiales J 690 M, González-Sampériz P, García-Ruiz JM. 2016. Linking land cover changes in the sub-alpine and montane 691 belts to changes in a torrential river. Land Degradation and Development 27: 179-189. DOI: $692 \quad 10.1002 / 1 d r .2294$.

693

694 Sass O, Oberlechner M. 2012. Is climate change causing increased rockfall frequency in Austria? Natural 695 Hazards and Earth System Science 12: 3209-3216

696

697 Schuerch P, Densmore AL, McArdell BW, Molnar P. 2006. The influence of landsliding on sediment supply 698 and channel change in a steep mountain catchment. Geomorphology 78: 222-235. 
699

700 Stott T, Mount N. 2007. Alpine proglacial suspended sediment dynamics in warm and cool ablation seasons:

701 Implications for global warming. Journal of Hydrology 332, 259-270.

702

703 Syvitski JPM, Kettner AJ, Peckham SD, Kao SJ. 2005. Predicting the flux of sediment to the coastal zone:

704 application to the Lanyang watershed, Northern Taiwan. Journal of Coastal Research 21 (3): 580-587.

705

706

Tarolli P, Sofia G. 2016. Human topographic signatures and derived geomorphic processes across

707 landscapes. Geomorphology 255: 140-161.

708

709

Trevisani S, Cavalli M, Marchi L. 2010. Reading the bed morphology of a mountain stream: a

710 geomorphometric study on high-resolution topographic data. Hydrology and Earth System Sciences 14: 393-

711 405. DOI: 10.5194/hess-14-393-2010.

712

713 Yu G, Wang Z, Zhang K, Chang T, Liu H. 2009. Effect of incoming sediment on the transport rate of bed

714 load in mountain streams. International Journal of Sediment Research 24: 260-273.

715

716 Zhu YM, Lu XX, Zhou Y. 2008. Sediment flux sensitivity to climate change: a case study in the

717 Longchuanjiang catchment of the upper Yangtze River, China. Global and Planetary Change 60: 429-442.

718

719

720

721

722

http://mc.manuscriptcentral.com/ldd 

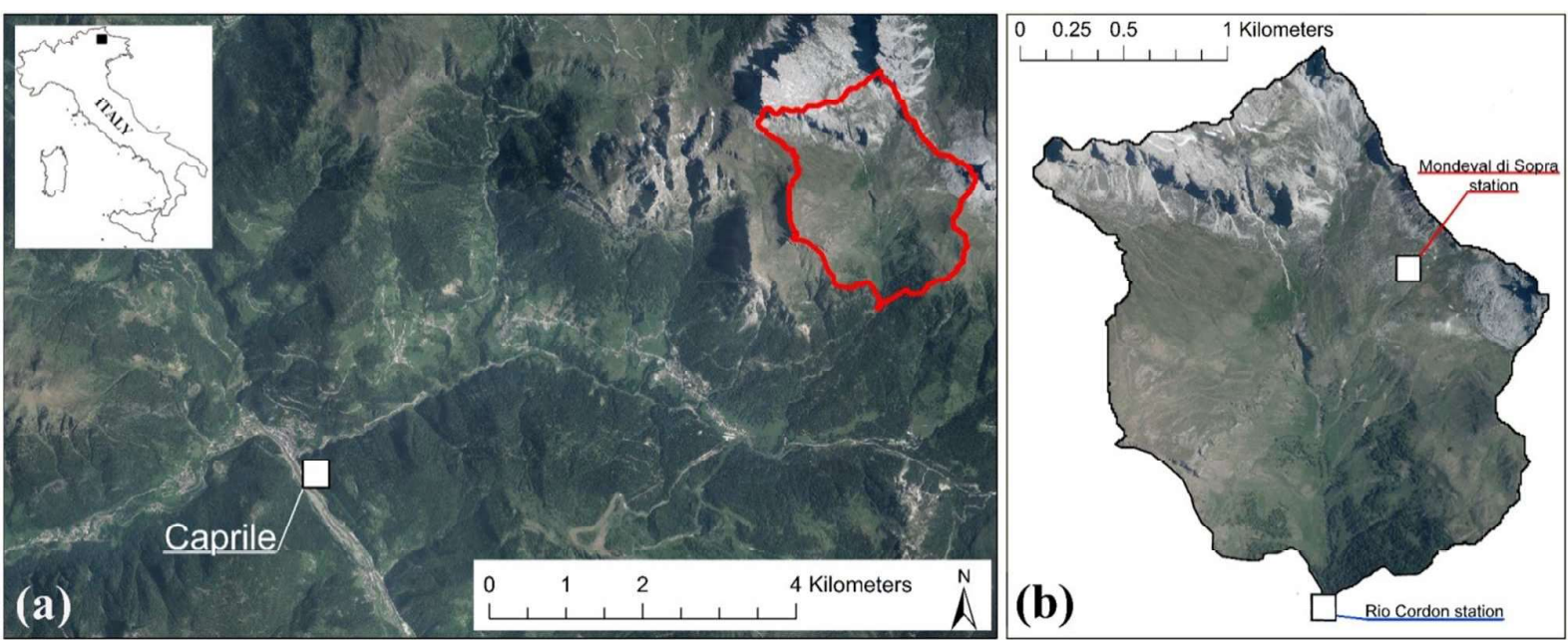

724

725

Figure 1: Location of the Rio Cordon basin (red outline) with respect to Caprile (a), and the Mondeval di Sopra and Rio Cordon stations in the basin (b). "Rio Cordon station" identifies both the meteorological and sediment transport monitoring station. The latitude-longitude (WGS84) of the Rio Cordon monitoring station are: $46.4505 \mathrm{~N}$ and 12.0953 E. 

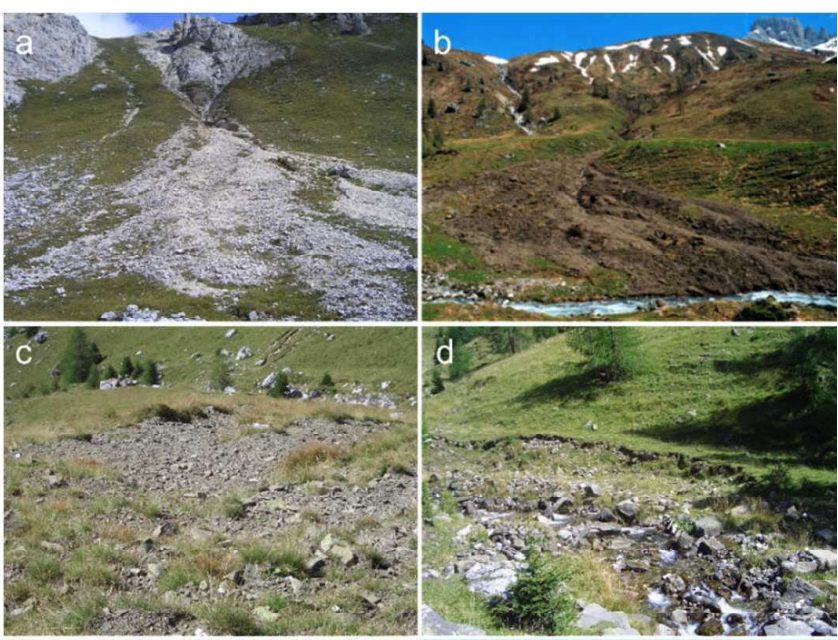

Figure 2: Different types of sediment source areas mapped in the Rio Cordon basin: debris flow-channel and -deposit (a); mud flow deposit generated by the evolution of a landslide occurred in 2001 (b); erosional area (c); eroded stream bank (d); shallow landslide 733
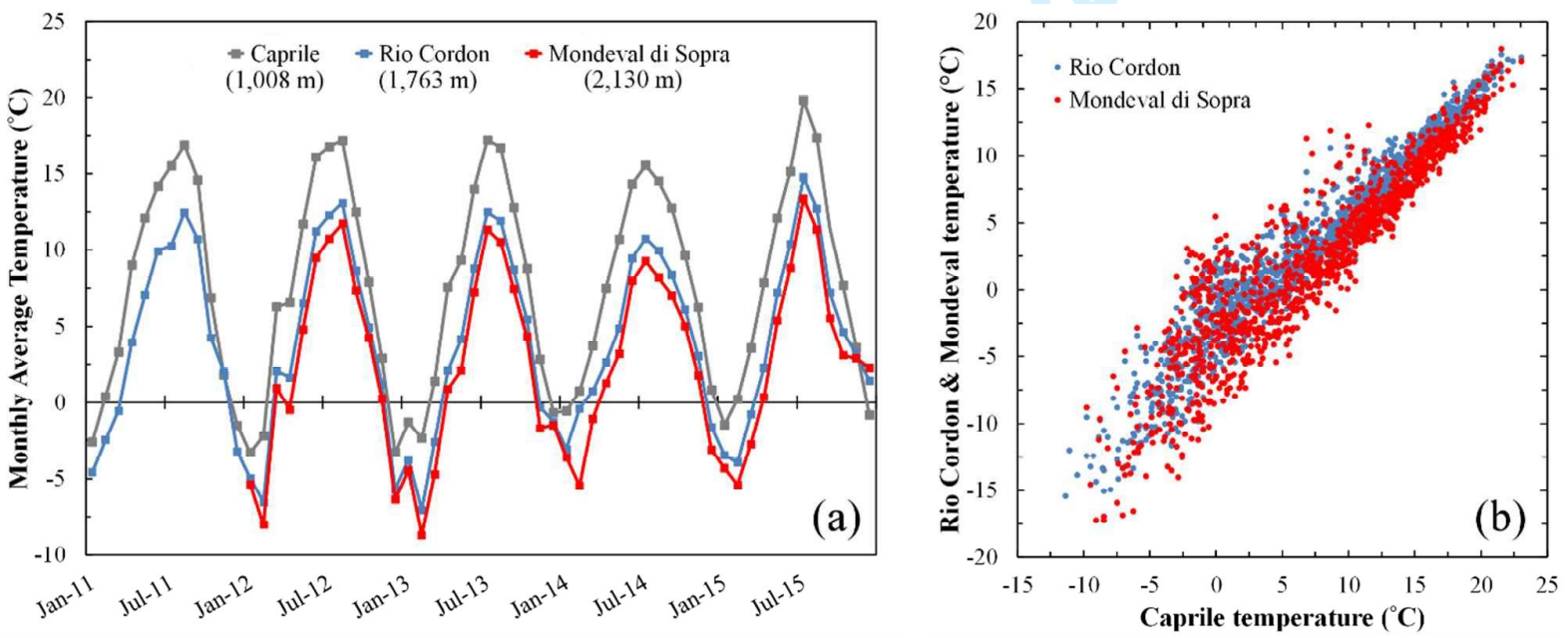

Figure 3: Monthly average air temperature in Mondeval di Sopra (2,130 $\mathrm{m}$ a.s.l.), Rio Cordon (1,763 m a.s.l.) and Caprile (1,008 $\mathrm{m}$ a.s.l.) (a). Rio Cordon - Caprile and Mondeval di Sopra temperature relationships (b). 
Figure 4: Average annual temperature in Caprile as the deviation from the 1986-2015 mean. Black dotted line is the 3 year moving average of the anomaly.

\section{1}
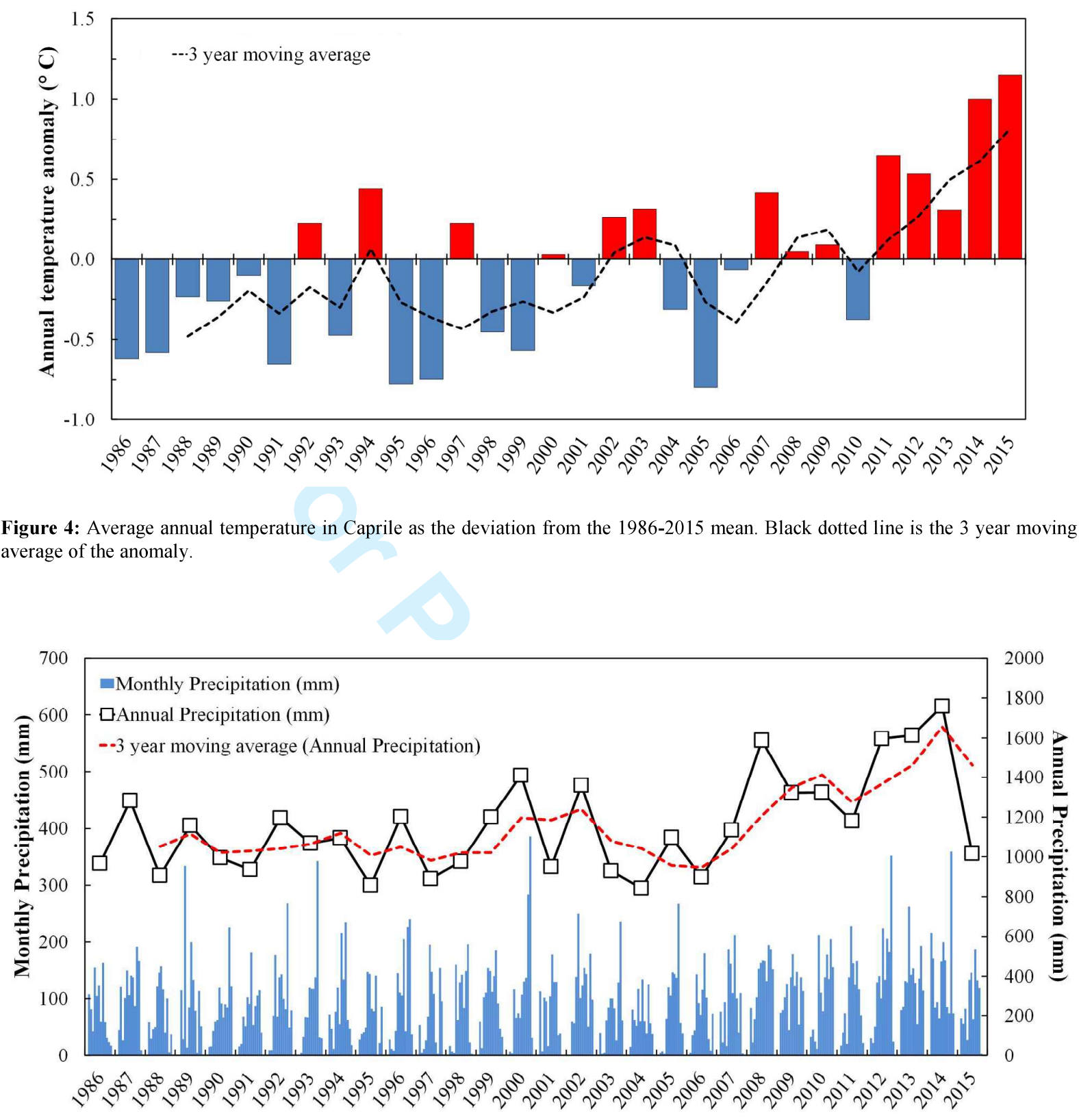

Figure 5: Monthly and annual precipitation in the Rio Cordon basin during the 1986-2015 period. The red dotted line is the 3 year moving average of the annual precipitation. 

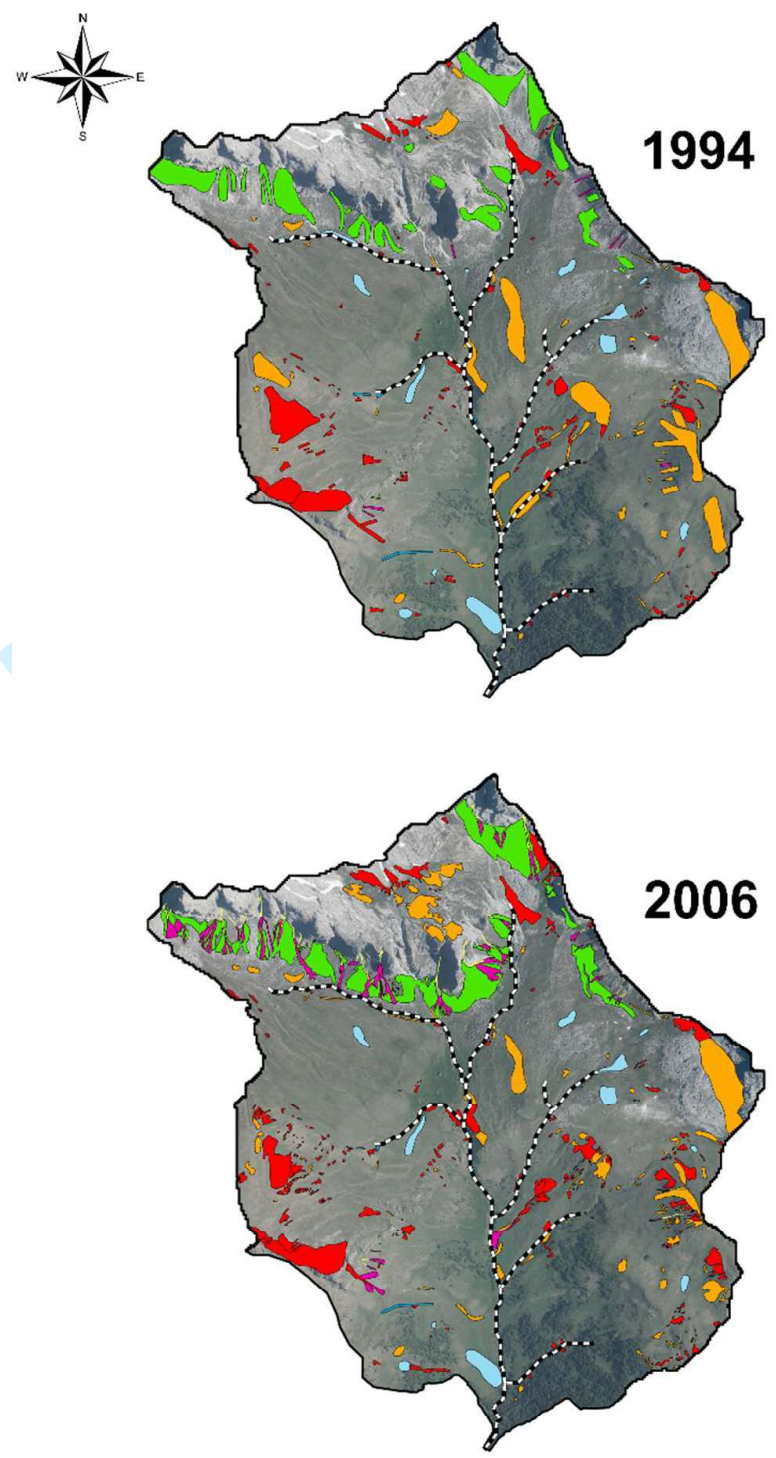

Figure 6: Sediment source inventories performed in the Rio Cordon basin in 1994, 2006 and 2016. 
1

2

$3 \quad 748$

$\begin{array}{ll}4 & 749 \\ 5 & \end{array}$

6

7

8

9

10

11

12

13

14

15

16

17

18

19

20

21

22

23

24

25

26

27

28

29

30

31

32

33

34

35

36

37

38

39

40

41

42

43

44

45

46

47

48

49

50

51

52

53

54

55

56

57

58

59

60

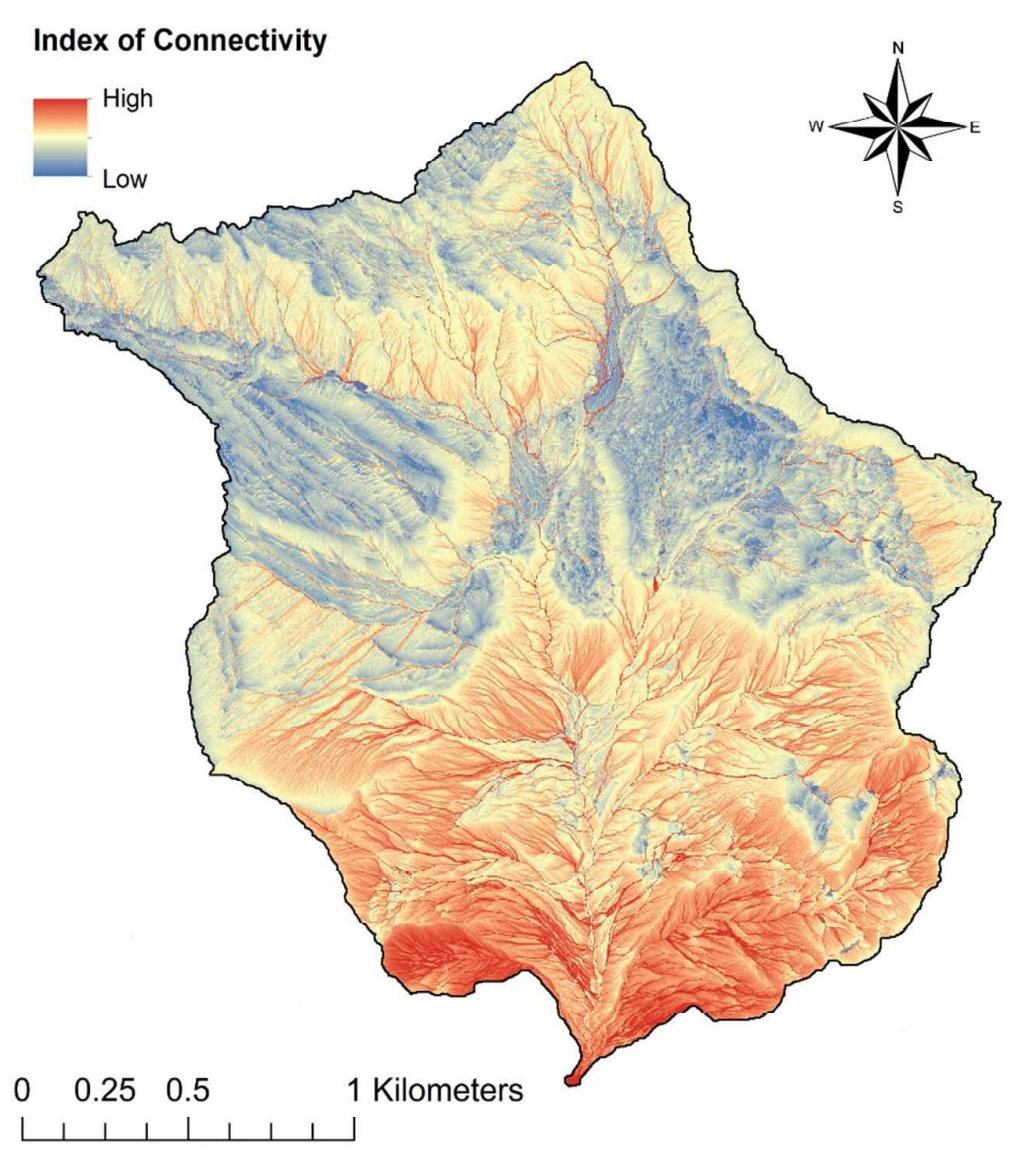

Figure 7: Sediment connectivity map 


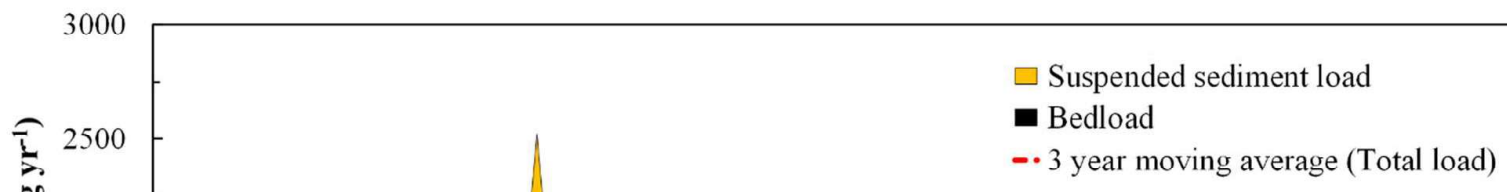

Figure 8: Annual sediment yield recorded by the Rio Cordon monitoring station during the 1986-2015 period. The red dotted line is 
760 Table I: Mean annual air temperature and annual precipitation recorded in the 1986-2015 period at Caprile and Rio Cordon

$\begin{array}{ll}760 & \text { Table I: Mean annual air temperat } \\ 761 & \text { meteorological stations, respectively. }\end{array}$

\begin{tabular}{|c|c|c|}
\hline & $\begin{array}{c}\text { Temperature } \\
\left({ }^{\circ} \mathrm{C}\right)\end{array}$ & $\begin{array}{l}\text { Rainfall } \\
(\mathrm{mm})\end{array}$ \\
\hline 1986 & 6.3 & 967 \\
\hline 1987 & 6.3 & 1281 \\
\hline 1988 & 6.7 & 907 \\
\hline 1989 & 6.6 & 1158 \\
\hline 1990 & 6.8 & 996 \\
\hline 1991 & 6.2 & 934 \\
\hline 1992 & 7.1 & 1194 \\
\hline 1993 & 6.4 & 1068 \\
\hline 1994 & 7.3 & 1096 \\
\hline 1995 & 6.1 & 856 \\
\hline 1996 & 6.2 & 1200 \\
\hline 1997 & 7.1 & 890 \\
\hline 1998 & 6.4 & 976 \\
\hline 1999 & 6.3 & 1200 \\
\hline 2000 & 6.9 & 1409 \\
\hline 2001 & 6.7 & 949 \\
\hline 2002 & 7.2 & 1358 \\
\hline 2003 & 7.2 & 930 \\
\hline 2004 & 6.6 & 841 \\
\hline 2005 & 6.1 & 1097 \\
\hline 2006 & 6.8 & 898 \\
\hline 2007 & 7.3 & 1134 \\
\hline 2008 & 7.0 & 1587 \\
\hline 2009 & 7.0 & 1322 \\
\hline 2010 & 6.5 & 1325 \\
\hline 2011 & 7.6 & 1180 \\
\hline 2012 & 7.4 & 1597 \\
\hline 2013 & 7.2 & 1612 \\
\hline 2014 & 7.9 & 1757 \\
\hline 2015 & 8.0 & 1016 \\
\hline
\end{tabular}


769 Table II: Type, extent and evolution of sediment sources over the inventories performed in the Rio Cordon basin in 1994,2006 and 770 2016. In 2006 and 2016, the debris flow type is the sum of the debris flow-channel and -deposit.

\begin{tabular}{|c|c|c|c|c|c|c|c|c|c|}
\hline \multirow[b]{2}{*}{ Type } & \multicolumn{3}{|c|}{1994} & \multicolumn{3}{|c|}{2006} & \multicolumn{3}{|c|}{2016} \\
\hline & $\begin{array}{l}\text { Area } \\
\left(\mathrm{m}^{2}\right)\end{array}$ & $\begin{array}{l}\text { Count } \\
\text { (n) }\end{array}$ & $\begin{array}{c}\text { Av.area } \\
\left(\mathrm{m}^{2}\right)\end{array}$ & $\begin{array}{l}\text { Area } \\
\left(\mathrm{m}^{2}\right)\end{array}$ & $\begin{array}{l}\text { Count } \\
\text { (n) }\end{array}$ & $\begin{array}{c}\text { Av.area } \\
\left(\mathrm{m}^{2}\right)\end{array}$ & $\begin{array}{l}\text { Area } \\
\left(\mathrm{m}^{2}\right)\end{array}$ & $\begin{array}{l}\text { Count } \\
\text { (n) }\end{array}$ & $\begin{array}{c}\text { Av.area } \\
\left(\mathrm{m}^{2}\right)\end{array}$ \\
\hline Debris flow & 8887 & 10 & 889 & 71623 & 78 & 918 & 70816 & 78 & 908 \\
\hline - channel & $n / a$ & $n / a$ & $n / a$ & 15340 & 38 & 404 & 18845 & 40 & 471 \\
\hline - deposit & $n / a$ & $n / a$ & $n / a$ & 56283 & 40 & 1407 & 51971 & 38 & 1368 \\
\hline Erosional area & 160241 & 66 & 2428 & 171050 & 98 & 1745 & 162406 & 85 & 1911 \\
\hline Eroded stream bank & 5517 & 25 & 221 & 3902 & 22 & 177 & 1734 & 22 & 79 \\
\hline Landslide & 149197 & 167 & 893 & 191797 & 195 & 984 & 195151 & 208 & 938 \\
\hline Active talus & 174423 & 24 & 7268 & 210182 & 26 & 8084 & 201316 & 26 & 7743 \\
\hline Rockfall deposit & 0 & 0 & 0 & 0 & 0 & 0 & 20676 & 1 & 20676 \\
\hline Total source areas & 498265 & 292 & 1706 & 648554 & 419 & 1548 & 652100 & 420 & 1553 \\
\hline Wetland & 46641 & 13 & 3588 & 43293 & 12 & 3608 & 43453 & 13 & 3343 \\
\hline Stabilized & $n / a$ & $n / a$ & $n / a$ & 2693 & 19 & 142 & 18773 & 33 & 569 \\
\hline Obliterated & $n / a$ & $n / a$ & $n / a$ & $n / a$ & $n / a$ & $n / a$ & 10719 & 5 & 2144 \\
\hline
\end{tabular}

771 

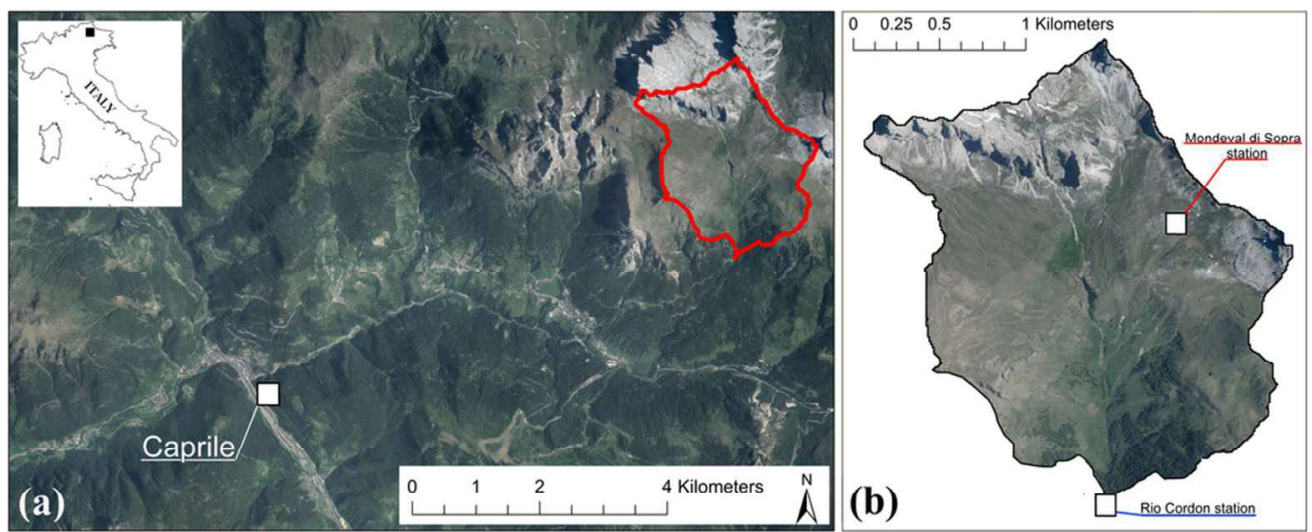

Figure 1: Location of the Rio Cordon basin (red outline) with respect to Caprile (a), and the Mondeval di Sopra and Rio Cordon stations in the basin (b). "Rio Cordon station" identifies both the meteorological and sediment transport monitoring station. The latitude-longitude (WGS84) of the Rio Cordon monitoring station are: $46.4505 \mathrm{~N}$ and $12.0953 \mathrm{E}$.

$44 \times 17 \mathrm{~mm}(600 \times 600 \mathrm{DPI})$ 


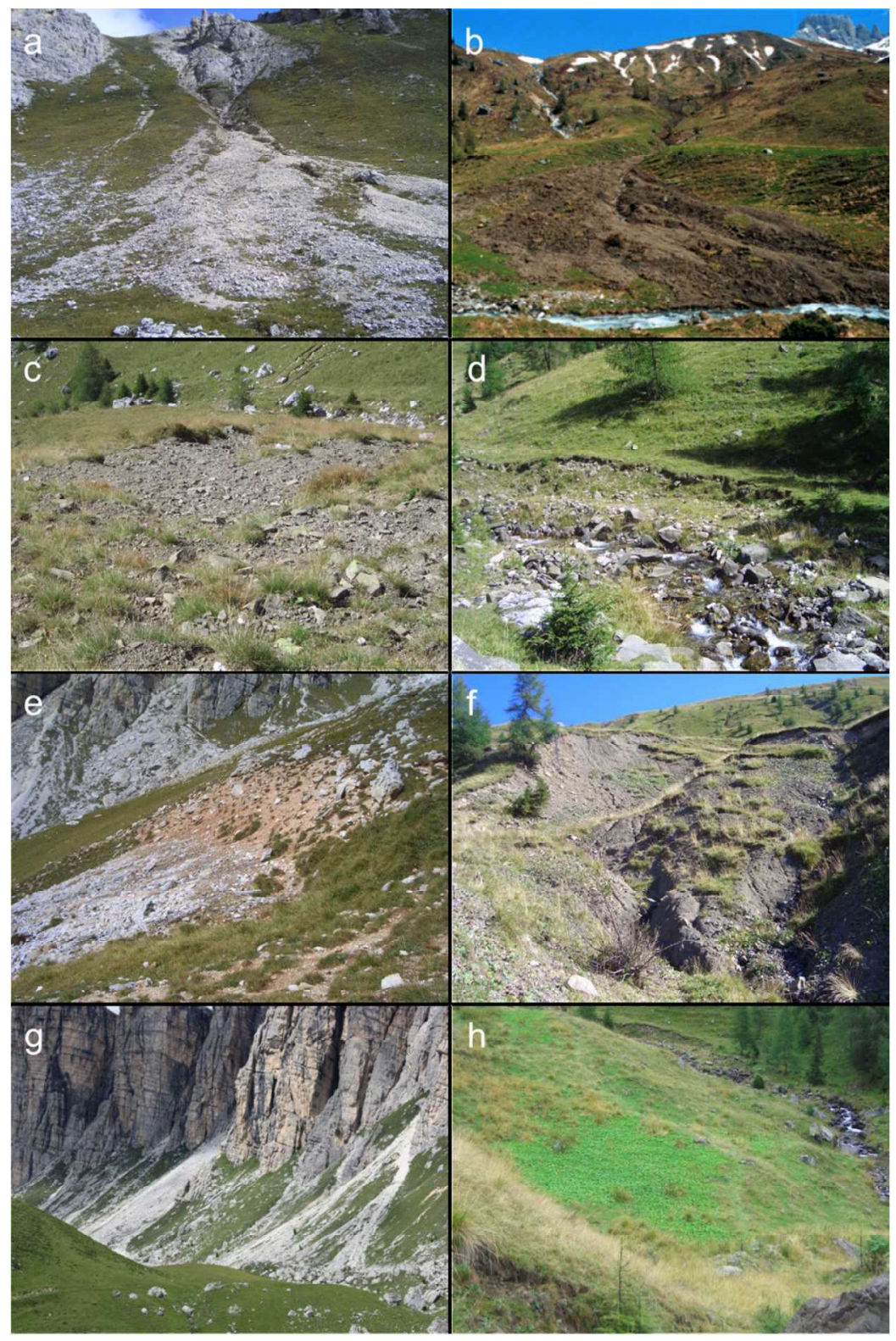

Figure 2: Different types of sediment source areas mapped in the Rio Cordon basin: debris flow-channel and -deposit (a); mud flow deposit generated by the evolution of a landslide occurred in 2001 (b); erosional area (c); eroded stream bank (d); shallow landslide (e); landslide which occurred in 2001 (f); active talus (g). Small wetland areas $(h)$ were also mapped.

$47 \times 71 \mathrm{~mm}(600 \times 600 \mathrm{DPI})$ 


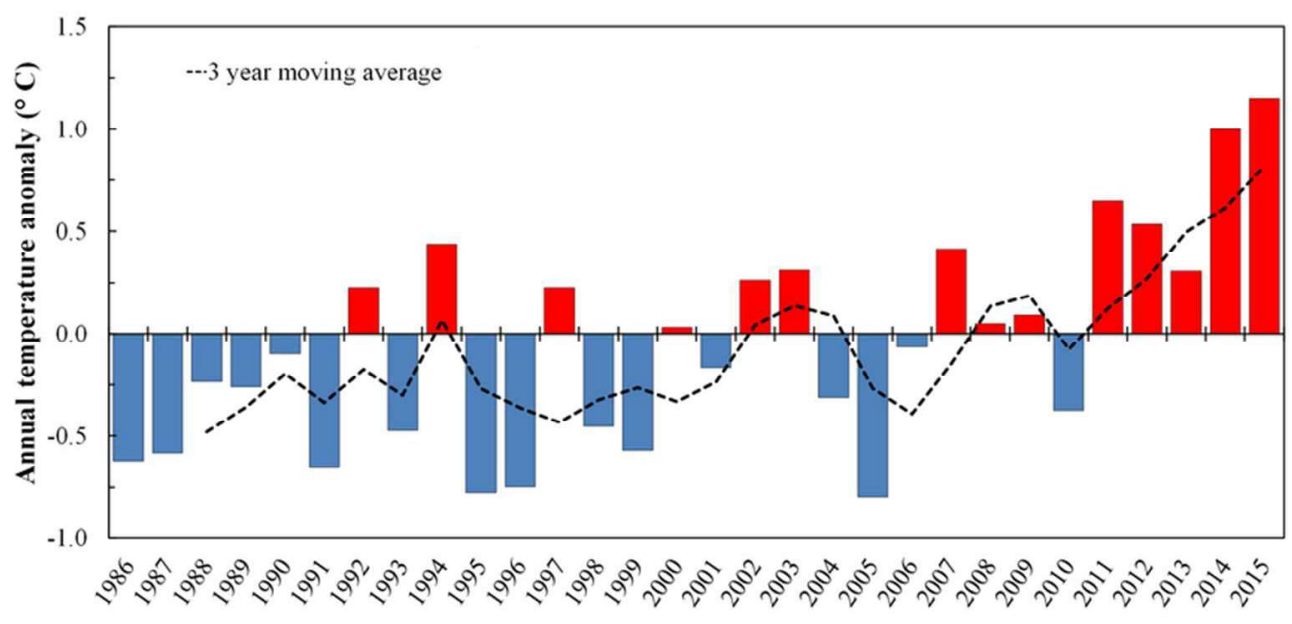

Figure 4: Average annual temperature in Caprile as the deviation from the 1986-2015 mean. Black dotted line is the 3 year moving average of the anomaly.

\section{$36 \times 17 \mathrm{~mm}(600 \times 600 \mathrm{DPI})$}


Figure 5: Monthly and annual precipitation in the Rio Cordon basin during the 1986-2015 period. The red dotted line is the 3 year moving average of the annual precipitation.

\section{$36 \times 16 \mathrm{~mm}(600 \times 600 \mathrm{DPI})$}



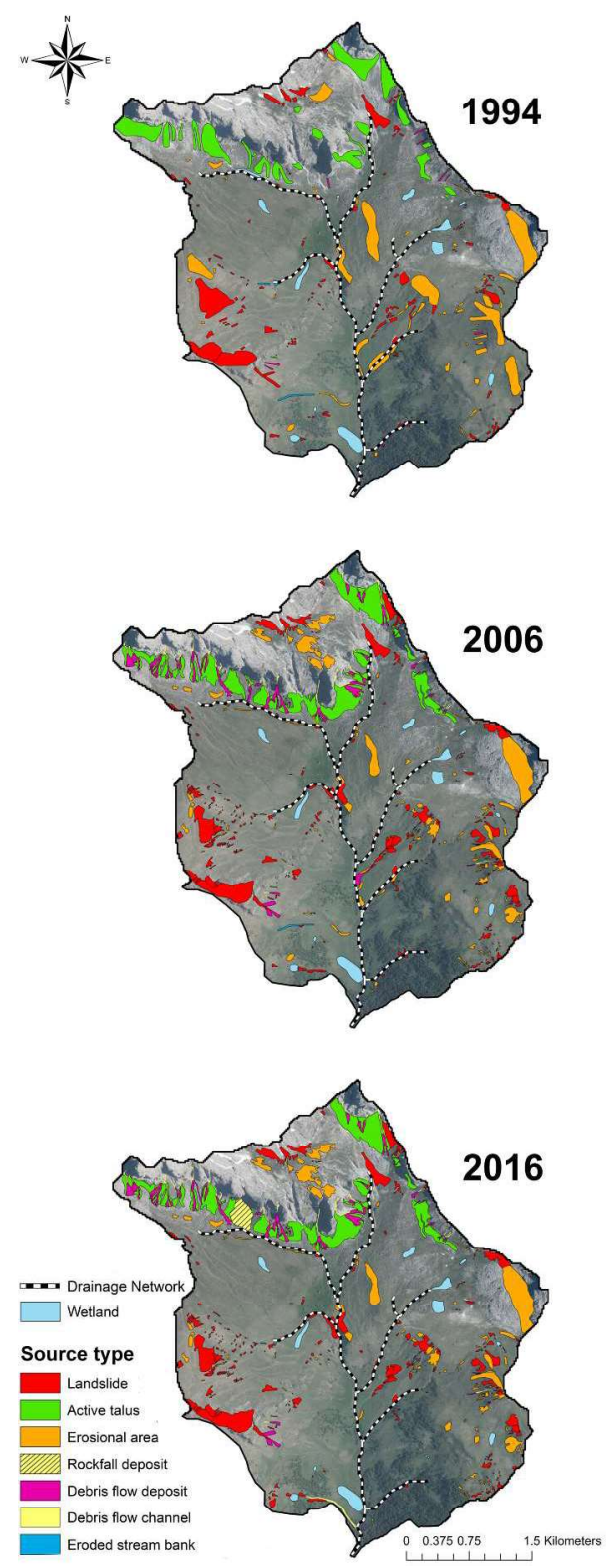

Figure 6: Sediment source inventories performed in the Rio Cordon basin in 1994, 2006 and 2016. $112 \times 300 \mathrm{~mm}(600 \times 600 \mathrm{DPI})$ 


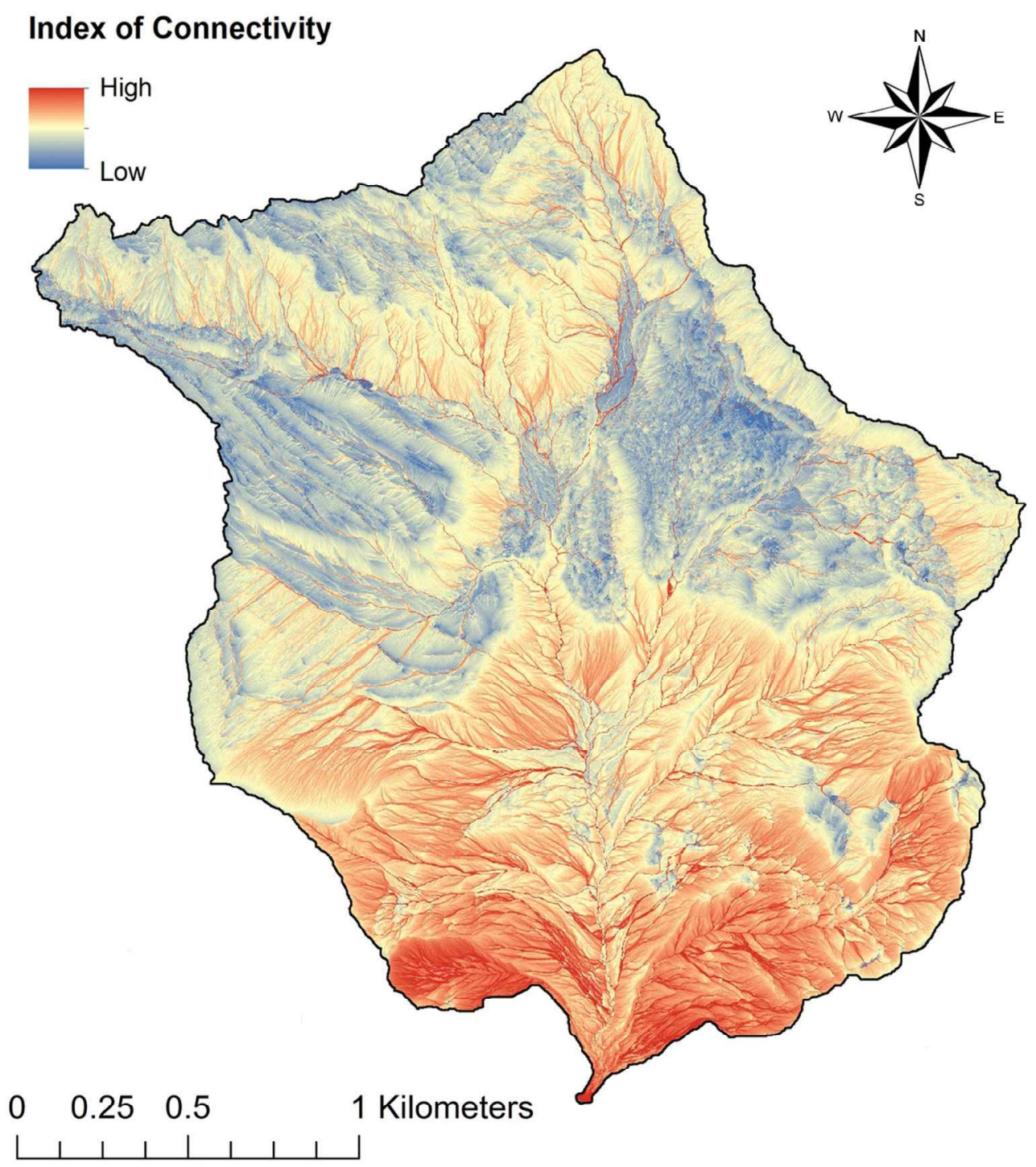

Figure 7: Sediment connectivity map

$53 \times 59 \mathrm{~mm}(600 \times 600 \mathrm{DPI})$ 
Figure 8: Annual sediment yield recorded by the Rio Cordon monitoring station during the 1986-2015 period. The red dotted line is the 3 year moving average of the total load (i.e. SSL $+\mathrm{BL}$ )

\section{$38 \times 19 \mathrm{~mm}(600 \times 600$ DPI $)$}

